\title{
Analysis of the Community-Based Media Approach to the Startup Media Business
}

\author{
Nadya Ariesta Komala Dewi ${ }^{1, *}$ Eriyanto $^{2}$
}

\author{
${ }^{1}$ Universitas Indonesia \\ ${ }^{2}$ Universitas Indonesia \\ *Corresponding author. Email: nadyaariestakd@gmail.com
}

\begin{abstract}
Media startup businesses that target the millennial generation are currently quite popular. IDN Times is an example of a highly visible media company that is focused on the millennial generation. To strengthen its identity as a voice of millennials and Generation Z, the IDN Times formed the IDN Community. The IDN Community has an important role within the IDN Times, so it is seen as key to the IDN Times. This study discusses the reasons media startup businesses use a community-based approach, using the concept of the Structure-Conduct-Performance (SCP) Paradigm and the Network Society. We use the case study method to present qualitative data. Data is collected in three ways, namely observation, document review, and interviews. The results show the IDN Times uses a communitybased approach because the IDN Community provides four benefits: (1) the Community can contribute content to the IDN Times, (3) the Community can provide input to the IDN Times on the latest news about millenials, (3) the Community provides feedback about various developments of the IDN Times, and (4) IDN Community members have the potential to become regular visitors to, and loyal readers of the IDN Times. The IDN Times' communitybased approach is inseparable from its observation that the growing community of networks is due to the development of technology.
\end{abstract}

Keywords: Online Media, Community, Millennial, Network Society, Startup Media

\section{INTRODUCTION}

Currently, media startup businesses that target the millennial generation (people born between 1981-1996) are quite popular. Among 43,000 online media outlets (Jawa Pos, 2018), many are well-known for having millennial segmentation, including Hipwee, Coils, Brilio, MBDC, Line today, and IDN Times. One of the reasons these media outlets exist is the large number of millennials. According to Bappenas data, there are approximately 90 million Indonesian millennials. This generation is also called the "technological literacy" generation. Of the various online media that have millennial segmentation, IDN Times is the most visible, and is extremely focused on millennial generation, as evidenced by the tagline "the voice of millennials and Gen Z." To strengthen that identity, the IDN Times formed the IDN Community.

The IDN Community is a forum of community writers created through information and communication technology. Many millennial generation writers have registered to become part of this network society, known as the IDN Community. Young writers who want to express their ideas through creative writing, publish their work to a wide audience and earn revenue, can take advantage of the IDN Community features available through the online media IDN Times. Not only writers join the online IDN Community, but also their editors and editors-in-chief; they all interact through the IDN Community.

The IDN Community was formed by two IDN Times CEOs as a place for millennials to share ideas or express themselves through creative writing. The IDN Times, which is also dubbed the "Buzzfeed of Indonesia," seeks to provide information to the millennial generation by appealing and adjusting to millennials' needs, and using a writing style that is memorable, not rigid, and differs from so-called "listicles."

Winston Utomo, CEO and Founder of IDN Media said, "We are very excited and enthusiastic to introduce the IDN Community. Until now, writing could only be a hobby for millennials in Indonesia. With this platform, 
they finally have the opportunity to turn their hobbies into a professional job.” (Dailysocial.id, 2017)

Furthermore, the Managing Partner of East Ventures, Willson Weather, one of IDN Media's investors, said, "the IDN Times Community is not just a writing platform. This platform contributes to the development of the nation's economy by opening up jobs throughout Indonesia, especially in remote areas where there are not many opportunities to work in the creative industry. This will be a major breakthrough in the media world." (Dailysocial.id, 2017)

Nowadays, many millennials are interested in becoming writers. Through blogs and social networking sites, millennials have begun to actively provide their opinions through writing. It often starts in the form of writing on social media such as Instagram, Twitter, and Facebook. Based on the 2019 Indonesia Millennial Report, $79.5 \%$ of millennials update their status on social media between 2-5 times per day.

With the speed and ease of accessing information via the internet or social media, millennials now access information more through TV and online media than from reading newspapers, magazines or tabloids (Kompas.com, 2019). As such, online media play an important role in providing millennials with information.

As a relatively new online media company, IDN Times has been able to attract up to 38.5 million visitors per month, publishing in-house content (on general topics from politics to lifestyle). Content is contributed by 90,000 community writers throughout Indonesia (Techinasia.com, 2019). The community-oriented media approach has become popular in Indonesia. According to the IDN Times' CEO, Winston Utomo, "Our community is the key to the IDN Times" (Techinasia.com, 2019)

This statement by the IDN Times CEO can be interpreted to mean that the IDN Times community has an important role in the IDN Times and is seen as key to the IDN Times' success. The IDN Community as a network society within the IDN Times has implications for the sustainability of the company, including an increase in the number of regular visitors and an increase in the amount of content on the IDN Times, which ultimately have a positive effect on advertising and ad revenues. Ernia Karina, the IDN Times' Community Manager said that content from the IDN Times Community contributes $40 \%$ of the IDN Times' total traffic.

The fact that IDN Community has a large number of members and has created the best-known writers' community for Indonesia's millennial generation is our main reason for analyzing the IDN Community. The research question we intend to pursue is: Why do media startup businesses use a community-based approach? By analyzing the IDN Community, this study provides an explanation as to why media startup businesses use a community-based approach. The analysis will provide insights to policy makers, organizations, and related industries to identify the causes of a community-based approach to creating a media business. Therefore, this study contributes to the research on media startup businesses and also provides insights into social change in Indonesia. Previous studies primarily focused on the emergence of citizen journalism as an alternative to professional journalism, rather than exploring the possibility of synergy between the two (Paulussen \& Ugille, 2008). This study views the IDN Community within the IDN Times as describing a successful model of a community-based approach to a media startup business.

\section{METHODS}

We use the case study method to present qualitative data for this analysis. The case study method is used because it can study cultural and social phenomena in actual events and settings (Denzin and Lincoln, 2004). Data is collected for this study in three ways, namely observation, document study, and interviews. This is an advantage of the case study approach, as findings or conclusions will be more convincing if based on several different sources of information (Yin, 2012). Data analysis was carried out by research in the field. The data obtained is analyzed with relevant theories and concepts, especially those relating to the communitybased approach to the media startup business.

\section{LITERATURE REVIEW}

\subsection{Structure-Conduct-Performance}

The Structure-Conduct-Performance (SCP) paradigm in industrial economics is used to connect elements of market structure with the behavior and performance of an industry. SCP theory states that market structure affects industry performance. This flow is based on the assumption that market structure influences company-level behavior, which affects company performance and therefore the industry in the aggregate as explained by Gilbert (1984).

Hiebert. et al (1991), suggest three analytical frameworks to explain various aspects of the work of media businesses. These frameworks are also relevant indicators in assessing the media industry's characteristics because they present basic information related to the uniqueness of mass media business operations. These three analytical frameworks are economic structure (structure), company operation (conduct), and company performance (performance). The SCP approach was introduced by Mason and then applied by Bain through interdisciplinary studies (Wirth and Bloch, 1995). The essence of the SCP approach to 
analyzing industry performance is the hypothesis that the performance of markets (or industries) is influenced by the behavior of companies in the market, while companies are influenced by various variables that shape the market structure (Wirth and Bloch, 1995).

\section{Structure}

The concept of structure describes the characteristics and composition of markets and industries in an economy (Ferguson \& Ferguson, 1994). Structure refers to the level of concentration of sellers and buyers, the height of entry barriers and the level of product differentiation in individual industrial markets. Porter details the elements of structure that can influence the competitive strength of an industry (Hiebert et al., 1991). According to Porter, there are five elements in the market structure, namely (1) new entrants, (2) suppliers, (3) buyers, (4) substitute products, and (5) competitors.

\section{Behavior (Conduct)}

Scherer and Ross (1990) suggest that behavior or conduct in the SCP paradigm is related to product strategy, innovation, and corporate advertising. It focuses on how companies set prices, whether independently or in collusion with other companies in the market, how companies decide on their advertising and research budgets and the level of expenditure devoted to this activity. According to Ferguson and Ferguson (1994), the term "conduct" refers to the company's behavior toward the market in determining prices (both independently or by agreement), product and advertising strategies, and research and innovation (Wirth and Bloch, 1995).

The business behavior of the media primarily consists of production and consumption activities. Production-related activities include (1) media goods, i.e., physical media products such as a newspaper or magazine, and (2) media services, referring to media content or to supporting activities needed to supply products, for example, news or other articles. The media industry's consumptionrelated activities include meeting the needs of its two target markets (media is a two-sided market), namely readers and advertisers. The existence of these two types of consumers is crucial for the survival of media institutions. Therefore, to maximize profits, media managers are always focused on the interests of both readers and advertisers. Therefore, consumer tastes and preferences are the benchmarks of the media production process.

\section{Performance}

Performance is measured by comparing company results across the industry with respect to price, quantity, product quality, resource allocation, production efficiency, etc. (Neuberger, 1997). Several criteria can be used to assess the economic performance of the media industry, including: corporate profits, production allocation and efficiency (i.e., using resources productively, and producing the right product(s) in both quantity and quality to achieve customer satisfaction), and the appropriate distribution of income. Additional performance variables that complement media industry decision-making include how companies in the media market provide equal opportunities to their employees. For the purposes of this analysis, these variables can be simplified into three categories: (1) efficiency, (2) use of technology, and (3) ability to increase audience access (readers/viewers/accessors).

\subsection{Network Society}

Developments in technology are impacting people's social lives and are helping to form a new order in society. According to Manuel Castell (2000), a network society is a society whose social structure is made of networks supported by microelectronic-based information and communication technology. The term network society describes the phenomenon of community-based communication activities facilitated by the use of information and communication technology (ICT). Various types of communication activities between individuals can take place because of ICT. Using ICT, specifically the internet, a network society is a community that can create, distribute and use information regarding a wide range of interests, including economic, political, and cultural (Rustam, 2017).

A network society has a strong attachment to the freedom of information and technology itself. Communities in the virtual world depend on the ability to access information that supports the community. Furthermore, the existence of the internet is especially essential for people who need a place to express things that cannot be done in the real world (Trisilowaty, 2017).

In network logic, the work is decentralized and the authority to make decisions is divided among the points that are intertwined in the network. There is no center in this context. Networks function using binary logic, inclusion or exclusion (Castells, 2000). Everything that is connected in the network is considered useful and important, while whatever is outside the network is considered non-existent. Members (or nodes) in the network that do not work will be replaced by new members (nodes), producing a new network structure. Although there is no "center", a given point or node may be more important than another, not because of a hierarchical structure but because of its ability to absorb and process information efficiently. Points or nodes that 
function at a lower standard, it will be replaced. Thus, the importance of a point is not determined by a particular feature, but rather because of its ability to be trusted by the network in sharing information (Habibi, 2011)

\section{RESULT AND DISCUSSION}

\subsection{Result}

With the development of technology, communitybased media approaches have become increasingly popular. IDN Times, part of a media startup called IDN Media, approached community-based media by forming the IDN Community in 2017. Previously, IDN Times ran like other online media, but in 2016, IDN Times started a pilot project, the IDN Times Community. According to IDN Times CEO, Winston Utomo, "Our community is the key to IDN Times" (Techinasia.com, 2019)

On February 7, 2017 IDN Times officially launched the IDN Times Community, applying the concept of gamification and offering rewards in the form of financial incentives to writers who actively joined. Winston Utomo, CEO and Founder of IDN Media said, "We are very excited and enthusiastic about launching the IDN Community. Until now, writing could only be a hobby for millennials in Indonesia. With this platform, they finally have the opportunity to turn their hobbies into a professional job.” (Dailysocial.id, 2017)

Furthermore, according to Ernia Karina, IDN Times Community Manager, "IDN Times wants to create a writing platform as a platform for millennials to write and work specifically in the world of writing. We wanted to be a mouthpiece and a place for millennials to voice opinions and also showcase their work. But along as it developed, it turned out that the IDN Times Community writing platform was well received by the readers, so we are also serious about developing the IDN Times Community platform."

The IDN community can be a forum for millennial and Generation $\mathrm{Z}$ writers who want to show their writing to, and share information with the public. Writers can hone and improve their writing skills because their writings will be assessed directly by professional editors, so they must meet journalistic standards. Editors provide feedback to authors as is the case with conventional media offices.

IDN Media is a leading multi-platform media company for millennials and Gen-Z'ers in Indonesia. Thus, the IDN Community is also expected to be a means for people in that target market to study and work professionally. The IDN community can be a place to become a professional writer and cultivate quality writing. As quoted in dailysocial.id, East Ventures'
Managing Partner Willson Weather, an IDN Media investor, added,

"The IDN community is not just a writing platform. This platform contributes to the development of the country's economy by opening jobs in all regions of Indonesia, especially in remote areas where there are not many opportunities to work in the creative industries. This will be a major breakthrough in the media world."

In an interview, Ernia Karina, IDN Times' Community Manager explained the IDN Community in more detail.

"The IDN Times Community is a free writing platform based on User Generated Content (UGC) for millennials and Gen-Z'ers who have interests and hobbies in the world of writing. Members can send posts and IDN Times will publish them to be read by millions of readers in Indonesia. Through this platform, writers can get cash incentives. The IDN Community differs from other media in that we have a gamification system, a selection/curation system from our editor, and a cash reward incentive. We have the ability to rank community writers and we provide financial incentives for active community writers; the page views of their articles that have been published are converted to points, and the points can be exchanged for cash. Every 100 views $=1$ point, and 500 points $=$ Rp.50,000. We apply strict selection criteria to the articles we receive, with a dedicated editor to handle articles from community writers. The editor selects and also gives feedback directly to the community writer, which is not done by other media that also have UGC platforms, such as Kumparan, Hipwee, and UC News."

Ms. Karina further explained the benefits associated with joining the IDN Times Community:

"One benefit is certainly the financial incentive that can result from writing for the IDN Times Community. But aside from money, there are definitely other benefits to be gained from being an active member of the Community. The IDN Times involves members in activities and events held by IDN Media and we offer them free tickets, etc. Community members have priority to become interns or to work with IDN Times, if there are job openings, and will receive recommendations (according to their skills and record as active users). In addition, community members can gain a great deal of knowledge about the world of writing from the editor."

\subsection{Discussion}

Hiebert. et al. (1991) suggested three analytical frameworks to explain various aspects of the work of the media business. These three frameworks are at the same time relevant indicators to assess the characteristics of the media industry, because they 
present basic information related to the uniqueness of mass media business operations. As explained previously, the three analytical frameworks include economic structure (structure), company operation (conduct), and company performance (performance). These three analytical frameworks can explain why media startup businesses use a community-based approach.

\subsubsection{Structure}

The definition of "structure" refers to the market structure that is usually determined by the ratio of market concentration. Market concentration ratio is a comparison that measures the distribution of market share in the industry. The structure describes the characteristics and composition of markets and industries in an economy (Furguson, 1994). Structure refers to the level of concentration of sellers and buyers, the height of entry barriers and the level of product differentiation in individual industrial markets (Shepherd, 1985). David E. Porter (Hiebert et al., 1991) details elements in the structure that can influence the competitive strength of an industry. According to him, there are five elements in the market structure, namely (1) new entrants, (2) suppliers, (3) buyers, (4) substitute products, and (5) competitors.

IDN Times is part of IDN Media, a media startup in Indonesia. There are many newcomers to the media industry in the online media market and IDN Media is counted as one of them. As a newcomer, IDN Media, through IDN Times, made a breakthrough by building the IDN Times Community. The IDN Times Community is a free writing platform based on UGC for millennials and Gen-Z'ers who have interests and hobbies in the world of writing. Members can send posts and IDN Times will publish them to be read by millions of readers in Indonesia. UGC-based writing platforms are owned by other media, but the existence of a dedicated editor to handle articles from community writers distinguishes the IDN Times Community from other media.

"The editor selects content and also gives feedback directly to the community writer. This is not done by other media that also have UGC platforms, such as Kumparan, Hipwee, and UC News" (Interview with Ernia Karina, IDN Times Community Manager)

The IDN community can be a suitable forum for millennials and Generation $\mathrm{Z}$ writers who want to show their writing to the public and share information with the public. Writers can hone and improve their writing skills because their writings will be assessed directly by professional editors, so they must meet journalistic standards. Editors provide feedback to authors as is the case with conventional media offices.
The community writers at IDN Times are viewed as additional journalists who provide content for the IDN Times. The content on IDN Times is not only written by professional journalists but also by community writers. Ernia Karina, IDN Times Community Manager said that articles from the IDN Times Community contributed $40 \%$ of IDN Times' total traffic.

As quoted on Techinasia.com, as a relatively new online media company, IDN Times has been able to attract up to 38.5 million visitors per month, and publish in-house content ranging from general topics such as politics to lifestyl). IDN Times visitors (buyers) are also supported by the presence of access conducted by the IDN Times Community in the online media IDN Times.

IDN Times tries to make policies that are different from its competitors' policies. As noted previously, the IDN Times has a gamification system, a selection/curation system from the editor, and a reward incentive in the form of cash for writers who are members of the IDN Community. These things are the advantages of the IDN Times. The presence of the community and community engagement with IDN Times, makes media startups like IDN Times different from other media. But until now, IDN Times has not prepared a replacement product in anticipation.

\subsubsection{Conduct}

Scherer and Ross (1990) suggest that behavior or conduct in the SCP paradigm is related to product strategy, innovation, and corporate advertising. It focuses on how companies set prices, whether independently or in collusion with other companies in the market, how companies decide on their advertising and research budgets and the level of expenditure devoted to this activity. According to Ferguson and Ferguson (1994), the term "conduct" refers to the company's behavior toward the market in determining prices (both independently or by agreement), product and advertising strategies, and research and innovation (Wirth and Bloch, 1995). The business behavior of the media primarily consists of production and consumption activities. Production-related activities include (1) media goods, i.e., physical media products such as a newspaper or magazine, and (2) media services, referring to media content or to supporting activities needed to supply products, for example, news or other articles. The media industry's consumption-related activities include meeting the needs of its two target markets (media is a two-sided market), namely readers and advertisers. The existence of these two types of consumers is crucial for the survival of media institutions. Therefore, to maximize profits, media managers are always focused on the interests of both readers and advertisers. Therefore, consumer tastes and preferences are the benchmarks of the media production process. 
IDN Times, as an online media business, pays attention to its media production and consumption activities. IDN Times' production activities include two products for media goods: IDN Times in the form of news portals that can be accessed via the internet (on computers, smartphones and tablets), and as a media service, in which IDN Times displays a variety of content such as text and video news. This content covers a variety of topics, ranging from general topics, politics, health to lifestyle. Content on IDN Times is produced by official journalists from IDN Times but also by the IDN Times community writers. To produce a large amount of content at the level of established media, IDN Times uses content written by community writers, checked again by editors to ensure it is suitable for publication.

According to Winston, CEO of IDN Media, "Our community is the key to the IDN Times, because you cannot hire 500 people to write 500 articles." This means that IDN Times uses the IDN Community to produce content. With the number of IDN Community members reaching 90,000, IDN Times is able to produce the same amount of content as online media companies that have many staff journalists, such as detik.com.

The IDN Times content is unique compared to other media, as it is in the form of quiz and listicle content. Quoted on Techinasia.com, according to IDN Media CEO, Winston, "From the start, 95 percent of our content - aside from hard news and investigations - had to be in the form of lists," Winston said. "Why? We target millennials and Generation Z-ers. They spend most of their time on Facebook and Instagram, which [basically] are in the format of electricity."

The IDN Times' content generally follows the American media source, Buzzfeed, with writing styles that are adapted to millenials, not rigid, and interesting.

Consumption activities include readers and advertisers, and the existence of both is crucial for the survival of media institutions. Therefore, to maximize profits, media managers are always oriented to the interests of readers and advertisers. That is why the tastes of most consumers will be the main benchmarks of the media production process.

With respect to consumption activities, IDN Times does several things. The company tries to present the latest, most relevant content or news for millennials and Gen-Z'ers in a writing style tailored to that target market. $95 \%$ percent of IDN Times content, including hard news and investigations, is intentionally brief. This is done in accordance with the style favored by its readers. The IDN Times also uses IDN Community to increase its number of readers. IDN Community members who are millennials and Gen-Z'ers are a gateway for IDN Times to get closer to its readers. Not infrequently the news written by IDN Community eventually became investigative news for the IDN Times. The IDN Times can find out the latest things from the writings or input provided by the IDN Community.

The IDN Times also encourages IDN Community writers to share news or content that has been officially published on IDN Times with friends through social media, to increase the number of visitors or readers of IDN Times. Content or news that appears on social media, has a greater chance of being visited and read by millenials. To further maximize the number of visitors or readers, the content is shared in the form of links to encourage people online to visit IDN Times.

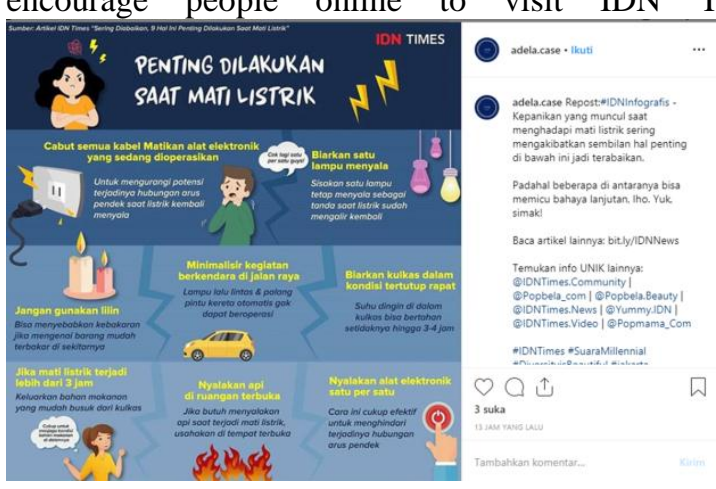

Figure 1 The example of sharing IDN Community's content (Source: www.instagram.com/idntimes).

With so many visitors and readers, it certainly increases traffic on the IDN Times. Thus, the number of advertisers on IDN Times is increasing.

As quoted on Techinasia.com, Winston CEO of IDN Media, said that IDN Media has never had a problem attracting clients. Indonesia's young population, the target demographic of the company, is very large. "It's not difficult to get clients to advertise. What's difficult is to make them clients who come again," he said.

Advertisers on IDN Media often do not stay with the site. One reason advertisers do not stay is that IDN Times' loading time is still not fast enough; it can take up to 10 seconds to load the entire display, including display ads. The IDN Times system has not been able to generate a perfect display with many advertisements in a short amount of time. This technical matter is being addressed continuously.

\subsubsection{Performance}

Several criteria can be used to assess the economic performance of the media industry, including: corporate profits, production allocation and efficiency (i.e., using resources productively, and producing the right product(s) in both quantity and quality to achieve customer satisfaction), and the appropriate distribution of income 
IDN Times strives for strong economic performance, including profits as well as proper production allocation and efficiency. IDN Times utilizes the IDN Community to reduce spending on recruiting journalists across Indonesia. IDN Times uses content written by community writers so that it can present a variety of content for its target audience. As quoted on Techinasia.com, according to SimilarWeb data, IDN Times is the 46th most visited website in Indonesia and is 8 th in the news and media category. The top three sites in that category are TribunNews (\#4), Detik (\#7), and Yahoo (\#10), all of which are linked to established media companies and target a general audience of readers.

Performance variables that complement media industry decision-making include how companies in the media market contribute to equal opportunities for their employees. For the purposes of this analysis, these variables can be simplified into three indicators: (1) efficiency, (2) use of technology, and (3) ability to increase audience access (readers/viewers).

IDN Times provides opportunities for its employees, including the IDN Community, to provide content through various methods such as via e-mail or through IDN Community features provided on the IDN Times. As a media company that targets millennials, the use of technology is a must for IDN Times. Almost everything is done through the use of technology, and while its millennial generation audience can access the IDN Times or the IDN Community platform via smartphones, the things done by IDN Times are still not enough; millennials are increasingly accessing information through podcasts and IDN Times does not yet have a presence in that channel.

Based on the description of the media startup business above, it can be seen that the IDN Times uses the IDN Community to help sustain its business, and the community-based media approach has become an important contributor to the IDN Times. The company states that the Community is the key to them. In an interview conducted with Ernia Kurnia, IDN Times' community manager, she explained,

"If the community is the key, it means that one of our goals is to become the \#1 media source for millennials and Gen-Z'ers in Indonesia. As IDN Times is still considered a startup, to be able to compete with large media networks that have been established for decades is not easy. IDN Times was founded by people who are completely new to the media industry, and we are also mostly young journalists. In terms of the numbers of writers/journalists we employ, we are clearly far behind when compared with other large media. As a startup media company, we are still unable to hire the number of reporters in seconds or stands, but if you want to defeat them, you must be able to at least compete in terms of the number of articles we produce. Therefore, we use and build a community so that friends who are active members of the IDN Times Community contribute to writing at the IDN Times."

This community-based approach is inseparable from observations made by IDN Times related to community segmentation and the development of the online world. IDN Times realizes that network societies are growing because of technology developments. According to Castell, community networks are development communities that are influenced by developments in information and information technology. Furthermore, according to Castell, in post-industrial society, networks allow communication to flow in any direction and at any structural level without the need to be referred or represented. Network societies describe the phenomenon of community communication activities through the use of ICT. Communication between individuals can take place because of ICT facilitates it. Members of the IDN Times Community, such as writers, editors, and the editor-in-chief can share any information. This communication can occur because of the IDN Community feature on the IDN Times site. This feature can be accessed using via the internet and members of the IDN Times Community are able to distribute, use and utilize information contained within the IDN Community.

Networks are a type of society that is attached to the freedom of information and technology itself. In this case, the community in the virtual world depends on freely available information Furthermore, the existence of the internet is essential for those who need space for expressions of things that cannot be done in the real world (Trisilowaty, 2017).

The IDN Community provides an opportunity for the public to share and access information. People who are members of the network known as the IDN Community are free to express and express opinions on a variety of topics in written form. The public is also given the freedom to argue on information provided by others. As long as they are connected to the internet, the public can access information and various information through the IDN Community and IDN Times.

Furthermore, in network logic, the work is decentralized and the authority to make decisions is divided among the points that are intertwined in the network. There is no center in this context. Networks function using binary logic, inclusion or exclusion (Castells, 2000). Everything that is connected in the network is considered useful and important, while whatever is outside the network is considered nonexistent. Members (or nodes) in the network that do not 
work will be replaced by new members (nodes), producing a new network structure. Although there is no "center", a given point or node may be more important than another, not because of a hierarchical structure but because of its ability to absorb and process information efficiently. Points or nodes that function at a lower standard, it will be replaced. Thus, the importance of a point is not determined by a particular feature, but rather because of its ability to be trusted by the network in sharing information (Habibi, 2011).

IDN Times has built the IDN Community where writers, editors, and editor-in-chief can give feedback to one another. All parties in the IDN Community play an important role. As with conventional mass media, the editor-in-chief has a more important role than the writer because he or she can determine whether a piece of writing is suitable for publication or not, whether it can be shared or not.

The IDN community has grown and evolved since its inception. The writers in the IDN Community are not limited to writing about the latest news and about Indonesia, but can also write on other topics (e.g., KPop). Because the writers belong to the same platform, the IDN Community, they come to know each other. It is not uncommon for writers in the IDN Community to write together in groups or to search for shared topics to increase their opportunities to write.

This community-based media approach to the media startup business has implications. This approach has increased the amount of internet traffic for the IDN Times. In addition, the community-based approach can increase the number of article produced by IDN Times. Ernia Karina, IDN Times Community Manager said that articles from the IDN Times Community accounted for $40 \%$ of total IDN Times traffic. Furthermore, the community-based approach can increase profits for IDN Media; according to Techinasia.com, IDN's CEO Winston said that 2018 was the first year IDN Media made a profit.

\section{CONCLUSION}

Viewing the media startup business, namely through the structure-conduct-performance paradigm, it can be seen that IDN Times utilizes the IDN Community to sustain its business. This community-based media approach has become an important element of the IDN Times' business model; in other words, community is the key to IDN Times. IDN Media uses a communitybased approach because it the presence of the IDN Community provides many benefits. First, the IDN Community can contribute content to the IDN Times. Second, the IDN Community can provide input on the latest news of interest to millennials. Third, the IDN Community can provide feedback on various developments at the IDN Times. Fourth, IDN Community members are loyal visitors to, and readers of IDN Times. Fifth, the IDN Community is a distributor of IDN Times content.

This community-based approach undertaken by IDN Times is inseparable from the company's observations related to community segmentation and the development of the online world. IDN Times realizes that network societies are growing because of the development of technology, which led to the development of the IDN Community.

\section{REFERENCES}

[1] Castells, M. (2000). The rise of the network society. Massachusets, Blackwell Publishers, Inc.

[2] Chandra, R. (2018). Dari. 43 Ribu Lebih Media Online, Hanya 0,4 Persen yang Profesional. Retrieved from https://www.jawapos.com/jpgtoday/09/02/2018/dari-43-ribu-lebih-media-onlinehanya-04-persen-yang-profesional/

[3] Denzin, N., \& Lincoln, Y. (2004). Handbook of qualitative research (2nd ed). CA: SAGE.

[4] Ferguson, P. R., \& Ferguson, G. J. (1994). Journal of Industrial Economics: Issues and perspectives (2nd ed). New York: New York University Press.

[5] Habibi, M. (2011). Memahami ACFTA dari Perspektif 'Masyarakat Jaringan'. Jurnal Kajian Wilayah, 2(1), 2011, 99-149

[6] Harususilo, Y. E. (2019). Survei: Bangun Tidur Generasi Milenial Langsung Pegang HP, kamu? Retrieved from https://edukasi.kompas.com/read/2019/01/30/1216 2041/survei-bangun-tidur-generasi-mileniallangsung-pegang-hp-kamu?page=all

[7] Hiebert, R. E., Ungurait, D. F., \& Bohn Thomas, W. (1991). Mass Media VI an introduction to modern communication. New York \& London: Longman.

[8] Karimudin, A. (2017). IDN times Community Beri Kesempatan Penulis Lepas Mendulang Pendapatan. Retrieved from https://dailysocial.id/post/idntimes-community/

[9] Mustika, P. (2019). Bagaimana Sebuah Blog Milenial Jadi Perusahaan Media dengan 50 Juta Pembaca. Retrieved from https://id.techinasia.com/idn-time-bermula-dariblog

[10] Neuberger, D. (1997). Structure, conduct and performance in banking markets. Thuenen-series of applied economic Theory 12. Rostock, Germany: University of Rostock, Institute of Economics. 
[11] Rustam, M. (2017). Network society, internet, [Dan Aktivitas Komunikasi Masyarakat]. Jurnal Studi Komunikasi dan Media, 21 No. 2 (Juli -(2017). Desember (pp. 165-180).

[12] Scherer, F. M., \& Ross, D. (1990). Industrial market structure and economic performance (3rd ed). Boston, MA: Houghton Mifflin.
[13] Wirth, M. O., \& Bloch, H. (1995). Industrial organization theory and media industry analysis. Journal of Media Economics, 8(2), 15-26. doi: 10.1207/s15327736 me0802_3.

[14] Yin, R. K. (2011). Studi Kasus: Desain dan Metode. Jakarta: Rajagrafindo Persada 